https://helda.helsinki.fi

\title{
A Word from the New Book Review Editors
}

\section{Benham, Claudia F.}

2020-03-03

Benham , C F \& Verbrugge , L N H 2020 , ' A Word from the New Book Review Editors ' ,

Society and Natural Resources , vol. 33 , no. 3 , pp. 307-308 . https://doi.org/10.1080/08941920.2019.1699295

http://hdl.handle.net/10138/330649

https://doi.org/10.1080/08941920.2019.1699295

acceptedVersion

Downloaded from Helda, University of Helsinki institutional repository.

This is an electronic reprint of the original article.

This reprint may differ from the original in pagination and typographic detail.

Please cite the original version. 


\section{A word from the new book review editors}

Claudia F. Benham ${ }^{\mathrm{a}^{*}}$ and Laura N. H. Verbrugge $\mathrm{b}^{\mathrm{b}^{*}}$

${ }^{a}$ College of Science and Engineering, James Cook University, Townsville, Australia;

${ }^{b}$ Department of Forest Sciences and Helsinki Institute of Sustainability Science (HELSUS), University of Helsinki, Helsinki, Finland

College of Science and Engineering, James Cook University, Townsville, Queensland, 4811 Australia. Email: Claudia.benham@jcu.edu.au

Department of Forest Sciences, Faculty of Agriculture and Forestry, University of Helsinki, P.O. Box 27 00014, Helsinki, Finland. Email: lauraverbrugge1 @ gmail.com 


\section{A word from the new book review editors}

In 1996, the incoming Book Review Editor, Steven R. Brechin, published a note outlining his hopes for the role and the most pressing concerns facing the readership of Society and Natural Resources. Central to these concerns, he wrote, were questions such as: "Who is right in our present debate, environmental optimists or environmental pessimists? How far will our present Congress go in altering our environmental and natural resource management policies and practices? How will the American public respond? Will the present crisis in international governance, caused by the Bosnian tragedy, spill over and contaminate, or even strengthen, international environmental efforts?” (Brechin 1996, p. 101).

Arguably, we confront a very different world in 2019. The pace of technological innovation over the last 24 years has created previously unimaginable possibilities and governance challenges. New generations have grown up and are making their voices heard. Geopolitical concerns have shifted, as have the lifestyles and aspirations of billions across the globe as new economic players take the stage. And sadly, on many measures, the environment is in worse shape than ever before. As we write this, parts of the United States and Australia have experienced some of the most intense and widespread wildfires in history; study after study has reported on unprecedented loss of terrestrial and marine biodiversity in ways that threaten both ecosystem integrity and human livelihoods; climate change continues seemingly unabated by international or domestic actions; and 2019 saw the second-lowest Artic sea-ice minimum since records began in 1978.

There have been other, more positive, changes too. IASNR has since expanded its international reach, and we take on this position from opposite sides of the globe Australia and Finland - reflecting some of the diversity of global perspectives and 
interests represented in our shared field. In addition to book reviews and review essays, Society and Natural Resources now publishes reviews of videos and films, current theatre productions, and art exhibitions that address issues relevant to the journal audience.

Nevertheless, the reflections of 1996 remain extremely prescient. Steven catalogued an explosion of publications exploring the environment-society nexus. This trend has only intensified with time, and has been bolstered by the rise of transdisciplinary and integrative research approaches that seek to fully understand how people and the environment interact. Furthermore, although much else has changed in the intervening 24 years, the fundamental questions and concerns that drive our work as scholars and practitioners in the fields of society and natural resources have not changed. Moreover, as Steven noted, the work we do at the society-environment nexus remains critical.

Since the first publication in 1988, an astounding number of book reviews have been published in Society and Natural Resources - 584 by our count. We are indebted to Associate Professor Kerry Ard, Associate Professor Kishi Animashaun Ducre, and our other predecessors for their work in providing this rich history for us to build upon. We now readily take on the task of publishing reviews that further advance scientific debate and guide readers to new publications in both established and newly arising research fields. We therefore warmly invite all IASNR members, and other scholars, to submit reviews, and look forward to working with you on this task over the coming three years. 
References:

Brechin, S. R. 1996. A word from the new book review editor. Society \& Natural Resources 9(1):101-102. 